\title{
ע Katsaus suomalaiseen CAM-tutkimukseen
}

Tämä katsausartikkeli käsittelee suomalaista täydentävän ja vaihtoehtoisen lä̈kinnän tutkimusta. Käytämme siitä lyhennettä CAM-tutkimus (CAM eli Complementary and Alternative Medicine, täydentävä ja vaihtoehtoinen lääkintä). Artikkelin tavoitteena on selvittää, millaista CAM-tutkimusta Suomessa on tehty ja mihin tutkimus on kohdistunut.

Tutkimusaineisto koostui CAM-hoitoja käsittelevistä 53 tutkimusartikkelista ja I2 väitöskirjasta ajanjaksolta 1980-2014. Aineisto haettiin kotimaisista ja ulkomaisista tietokannoista. Tutkimusmenetelmä oli sisällönanalyysi. CAM-tutkimusta tehtiin erityisesti 1990-luvulla ja 2000-luvun alussa. Useimmiten tutkimukset tehtiin yliopistossa tai yhteistyössä yliopistojen kanssa. Valtaosa aineistomme julkaisuista käsitteli CAM-hoitoja kokonaisuutena erittelemättä eri hoitomuotoja toisistaan. CAM-hoidoiksi tutkimuksissa luettiin erilaisia terveyden ylläpitoon tai sairauden hoitoon tarkoitettuja yrttejä, rohdoksia, homeopaattisia ja antroposofisia lääkkeitä, ruokavaliohoitoja sekä kehomielihoitoja, joista useimmin mainittiin henkiparannus, akupunktio ja vyöhyketerapia. Erittelemme artikkelissa suomalaisen CAM-tutkimuksen luokittelun kansainvälistä luokittelua mukaillen seuraavasti: I) CAM-hoitojen vaikuttavuuden ja käytettäryyden tutkimus, 2) CAM-hoitojen historian ja kansanperinteen tutkimus, 3) CAM-hoitojen käytön yleisyyden ja käyttäjäryhmien tutkimus, 4) hoitohenkilökunnan asenteiden ja suhtautumisen tutkimus. Lisäksi hahmottelimme viidennen - tosin Suomen kontekstissa hyvin vähäisen - luokan: CAM-ammattien tutkimus, tieteentutkimus ja hoitonäkemysten tutkimus. Suurin osa tutkimuksista kohdistui CAM-hoitojen käyttöön ja käyttäjätyyppeihin. Tulosten mukaan vähintään kolmannes aikuisista oli käyttänyt tai kokeillut jotakin CAM-hoitoa. Muita tutkimuskohteita olivat CAM-hoitojen vaikutukset, terveydenhuoltohenkilökunnan asenteet ja hoitojen historia. Vaikutustutkimuksista suurin osa kohdistui jäsenkorjaukseen, jolla todettiin olevan myönteisiä vaikutuksia. Lääkärien ja sairaanhoitajien CAM-asenteet osoittautuivat jakautuneiksi.

ASIASANAT:Täydentävä ja vaihtoehtoinen lääkintä, täydentävät ja vaihtoehtoiset hoidot, CAM-tutkimus, sisällönanalyysi, tieteentutkimus

PIA VUOLANTO, MINNA SORSA, PAULIINA AARVA, KAIJA HELIN

\section{JOHDANTO}

Täydentävän ja vaihtoehtoisen lääkinnän käyttö on eurooppalaiseen keskitasoon verrattuna maassamme melko yleistä. Vuoden 2014 European Social Survey -aineiston mukaan noin kolmannes suomalaisista oli käyttänyt jotakin tällaisen lääkinnän muotoa viimeisten 12 kuukauden aikana, mikä on laajempaa kuin monissa vertailumaissa (1). Laajan käytön taustojen selvittäminen on yh- teiskunnallisesti tärkeää, koska erilaisten hoitojen suosion on tulkittu liittyvän yhteiskunnassamme lisääntyvään tutkitun tiedon ja asiantuntijuuden kyseenalaistamiseen (2). Täydentävästä ja vaihtoehtoisesta läk̈kinnästä onkin Suomessa käyty kiistoja ja ammatillista keskustelua jo pitkään (315). Näissä kiistoissa tiedon rooli nousee merkittäväksi: jos jonkin hoidon tehosta on riittävästi luotettavaa tutkittua näyttöä, se voi vähitellen saada yleistä hyväksyntää ja se voidaan sisällyt- 
tää yleiseen terveydenhoitoon (9). Tämän katsauksen tavoitteena on tuottaa yleiskuva suomalaisesta täydentävää ja vaihtoehtoista lääkintää koskevasta tutkimuksesta. Pyrkimyksenämme ei ole ottaa kantaa vastakkainasetteluihin, vaan arvioida kriittisesti täydentävästä ja vaihtoehtoisesta lääkinnästä maassamme tuotettua tutkimustietoa. Tämän kautta osaltamme taustoitamme täydentävää ja vaihtoehtoista lääkintää koskevaa yhteiskunnallista keskustelua.

Suomessa käytössä olevia täydentävän ja vaihtoehtoisen lääkinnän muotoja ovat esimerkiksi antroposofinen lääkintä, aromaterapia, fytoterapia, homeopatia, kajava-terapia, perinteinen suomalainen jäsenkorjaus, perinteinen kiinalainen lääkintä ja vyöhyketerapia (9). Näistä käytetään eri käsitteitä - kuten uskomushoito, etnomedisiina tai puoskarointi -, joista osa on latautuneita hoitomuotojen kiistanalaisuuden vuoksi $(3,4,6,9,14)$, joten tietyn termin valinnalla saatetaan ilmaista omaa kantaa kiistassa. Käytämme artikkelissa täydentävästä ja vaihtoehtoisesta lääkinnästä kansainvälistä lyhennettä CAM, vaikka sitäkään ei voida pitää täysin neutraalina (14). Kansainvälisesti CAM-hoidoiksi luokitellaan monimuotoinen ja heterogeeninen joukko erilaisia hoitomuotoja, jotka ovat kehittyneet vallitsevan terveydenhoitojärjestelmän ulkopuolella (16), mutta kaikkia hoitoja ei pystytä näissäkään luokituksissa ryhmittelemään, koska hoitoja on niin kirjava joukko (9). Luokitukset myös vaihtelevat maasta ja kulttuuripiiristä toiseen: esimerkiksi Intiassa auyrveda-lääkintä on kulttuurisesti hyväksytympää kuin Euroopassa ja monille Intian kansalaisista taloudellisesti ainoa mahdollinen terveydenhuollon muoto (17). Erilaisia CAM-hoitoja on arvioitu olevan jopa 200 (9).

Puutteistaan huolimatta luokitukset auttavat hahmottamaan CAM-hoitojen kirjoa ja jäsentämään niiden eroja. Osassa CAM-hoidoista, kuten joogassa ja meditaatiossa, pyritään vaikuttamaan kehon toimintoihin mielen avulla. Toisissa hyödynnetään kasvien lääkinnällisiä vaikutuksia (monet luontaistuotteet ja ravintolisät), joissakin käytetään erilaisia ruokavalio- ja paastohoitoja. Jotkut hoidot perustuvat kehon käsittelyyn ja liikuttamiseen, kuten jäsenkorjaus, kiropraktiikka ja hieronta. Energiahoidoilla, kuten vyöhyketerapialla tai reiki-hoidolla, pyritään vaikuttamaan kehon energiakenttiin tai käsittelemään niitä.
Näiden lisäksi tavanomaisen lääkinnän ulkopuoliset terveydenhoidon järjestelmät - kuten homeopatia, antroposofinen lääkintä ja kiinalainen lääkintä - luokitellaan useimmiten omana kokonaisuutenaan (esimerkkejä luokituksista ks. 1, 9, 16, 18). Jäsentäessämme Suomessa tutkittuja CAM-hoitoja käytämme yhdysvaltalaista karkeaa luokittelua kolmeen: 1) ulkoisesti tai sisäisesti käytettävät valmisteet, kuten luontaistuotteet ja ravintolisät, 2) hoitotavat, joissa pyritään vaikuttamaan ihmiseen sekä kehon että mielen avulla ("mind and body practices"; käytämme näistä termiä kehomielihoidot), kuten jooga, kiropraktiikka, meditaatio ja osteopatia sekä 3) kokonaiset hoitojärjestelmät, kuten auyrveda, kiinalainen ja antroposofinen lääkintä (18).

\section{CAM-TUTKIMUS KANSAINVÄLISESTI JA SUOMESSA}

CAM-tutkimuksella tarkoitamme tutkimusta, joka kohdistuu yhteen tai useampaan CAM-hoitoon. Kokoavaa yhteenvetoa CAM-hoitojen suomalaisesta tutkimuksesta ei ole tätä katsausta aiemmin tehty. Kansainvälisesti CAM-tutkimusta on eritelty seuraavaan tapaan (ks. 19-20). Kliininen CAM-tutkimus on selvittänyt CAM-hoitojen tehoa, vaikuttavuutta ja käytettävyyttä (esim. 2122). Oman alueensa muodostaa CAM-hoitojen historian ja kansanperinteen tutkimus (esim. 3, 23). Terveyssosiologian, -antropologian ja terveystieteiden CAM-tutkimuksessa on etsitty tärkeimpiä CAM-käyttäjäryhmiä ja analysoitu syitä CAMhoitojen käyttöön (19-20, 24). Näiden alojen CAM-tutkimus on suuntautunut myös CAM-hoitajien professionalisoitumiseen ja organisoitumiseen $(19,25)$ eri maissa, muun muassa Saksassa (26), Portugalissa (27), Iso-Britanniassa (28) ja Australiassa (29). Lisäksi näillä aloilla on tutkittu myös terveydenhuollossa toimivien, erityisesti lääkärien (30) ja sairaanhoitajien (31-32) asenteita CAM-hoitoja kohtaan sekä terveydenhuoltohenkilökunnan ja CAM-hoitajien vuorovaikutusta (33), kuten myös CAM-hoitojen tarjontaa terveydenhuoltojärjestelmän sisällä (34-35).

Edellä esitetty luokittelu toimii tämän katsauksen teoreettisena taustana. Erittelemme artikkelissa suomalaisen CAM-tutkimuksen luokittelun kansainvälistä luokittelua mukaillen seuraavasti: 1) CAM-hoitojen vaikuttavuuden ja käytettävyyden tutkimus, 2) CAM-hoitojen historian ja kansanperinteen tutkimus, 3) CAM-hoitojen käytön yleisyyden ja käyttäjäryhmien tutkimus, 
4) hoitohenkilökunnan asenteiden ja suhtautumisen tutkimus. Lisäksi hahmottelimme viidennen - tosin Suomen kontekstissa hyvin vähäisen - luokan: CAM-ammattien tutkimus, tieteentutkimus ja hoitonäkemysten tutkimus.

CAM-tutkimuksen on todettu lisääntyneen 1990-luvulta lähtien sekä lääketieteellisissä lehdissä että CAM-tutkimukseen painottuneissa julkaisuissa (36-38). Joissakin maissa on perustettu erityisiä CAM-tutkimuksen keskuksia; Maailman terveysjärjestön mukaan niitä on eri maissa yli 70 (17). Pohjoismaissa toimii NAFCAM (Norway's National Research Center in Complementary and Alternative Medicine) norjalaisessa Tromssan yliopistossa. Se on yksi kahdesta eurooppalaisesta Maailman terveysjärjestön CAM-tutkimuksen yhteistyökeskuksesta, joita on eri puolilla maailmaa parikymmentä (39). Ruotsissa CAM-tutkimuskeskus toimii Karoliinisessa instituutissa (Osher Centre for Integrative Medicine).

Suomessa ei ole CAM-tutkimuksen keskusta, vaikka sellaisen perustamista on kaavailtu viimeisimmässä sosiaali- ja terveysministeriön selvityksessä, jossa esitettiin myös CAM-tutkimustoiminnan tehostamista, CAM-hoitoja koskevan tietopankin perustamista Terveyden ja hyvinvoinnin laitokseen ja CAM-hoitojen haittatapahtumien, virheiden ja vahinkojen tiedonkeruuta (9). Artikkelimme vastaa osaan näistä jo vuoden 2009 selvityksessä esitettyihin tiedontarpeisiin, koska se selvittää suomalaisen CAM-tutkimuksen tilannetta ja kokoaa tietoa CAM-hoitoja koskevasta tutkimuksesta maassamme pitkällä aikavälillä. Sellaisena se tarjoaa pohjaa poliittiselle keskustelulle, muttei pyri antamaan valmista vastausta maamme CAM-tutkimuksen organisoimisesta tulevaisuudessa eikä osallistumaan väittelyihin CAM-hoitajien sääntelystä tai CAM-tutkimuksen yhteiskunnallisesta tarpeellisuudesta tai tarpeettomuudesta.

\section{TUTKIMUKSEN TARKOITUS, AINEISTO JA TUTKIMUSMENETELMÄT}

Pyrimme artikkelissamme selvittämään, millaista CAM-tutkimusta Suomessa on tehty. Tarkoitus on muodostaa kokonaiskäsitys suomalaisesta CAM-tutkimuksesta. Kysymme: Millaista CAM-tutkimusta Suomessa on tehty ja mihin tutkimus on kohdistunut?
Aineisto koostuu suomalaisista ja ulkomaisista CAM-tutkimusartikkeleista sekä suomalaisista CAM-tutkimuksen väitöskirjoista. Valintakriteerit olivat seuraavat: Tutkimus, jonka aineisto oli kuvattu ja joka oli julkaistu tieteellisessä lehdessä, kirjassa tai raportissa. Siinä tuli olla vähintään yksi suomalainen tekijä. Tutkimusaineiston (tai sen osan) piti olla kerätty Suomessa. Tutkimuksen piti kohdistua ihmisaineistoon (ei eläinten hoitoon). Mukaan otettiin yksi tutkimus, jossa ihmisen hoitoon tarkoitetun aineen käytettävyyttä tutkittiin eläinkokeen avulla.

Aineiston muodostumisen vaiheet on havainnollistettu kuviossa 1. Täydellinen lista aineistosta on liitteessä 1. Hakusanoiksi valitsimme CAM-hoitojen yleistermejä. Niillä etsimme tutkimuksia, joiden otsikossa, abstraktissa tai asiasanana oli mainittu joku termeistä, jotka on lueteltu kuviossa 1 . Tulosten kuvauksessa viittaamme artikkeleihin liitteessä mainituin kirjainnumeroyhdistelmin (a1-a53) ja väitöskirjoihin versaalikirjaimin (A-L).

Vaiheessa 1 teimme haun heinäkuussa 2015 suomalaisista Arto ja Medic -tietokannoista käyttäen yleiskäsitteitä, ja rajasimme hakukriteereistä pois yksittäiset hoitomuodot. Vaiheessa 2 teimme syyskuussa 2016 haun ulkomaisissa Scopusja Medline-tietokannoissa käyttäen käsitettä "complementary therapies". Molemmissa hauissa valitsimme ensin otsikon perusteella aihepiiriltään tutkimukseemme sopivat ja sen jälkeen rajasimme julkaisuihin, joissa oli tutkimusaineisto kuvattuna; myös systemaattinen kirjallisuuskatsaus hyväksyttiin. Rajasimme aineistoa molempien vaiheiden päätteeksi siten, että mukaan otettiin vain tutkimukset, joissa tutkitut hoidot löytyivät Cochrane-tutkimuksissa käytetystä hoitomuotojen luokituksesta, joka sisältää yli 250 CAM-hoitomuotoa $(16,18,42)$. Tämän lisäksi pidimme mukana suomalaisia kansanlääkintätapoja käsittelevät tutkimukset. Lopuksi poistimme päällekkäiset artikkelit.

Vaiheessa 3 etsimme Medic- ja Melinda -tietokannoista suomalaiset CAM-väitöskirjat (10 $\mathrm{kpl}$ ). Mukaan otettiin lisäksi tämän katsauksen kirjoittajan väitöskirja (K) ja väitöskirja, jota siinä tutkitaan (E), vaikka nämä eivät hakusanoilla löytyneetkään, perustelunamme oli, että näissä käsiteltiin tutkimuksemme kannalta olennaisia, kiistanalaisia CAM-tutkimukseen liittyviä kysymyksiä. 
Kuvio 1. Aineiston haku tietokannoista valinta- ja poissulkukriteereineen.

VAIHE 1. Hakusanat: CAM-terapia, complementary medicine, epäviralliset hoitomuodot, integratiivinen lääketiede, kansanparannus, luontaishoidot, luontaislääkintä, täydentävät hoitomuodot, uskomushoidot, vaihtoehtoiset hoidot, vaihtoehtohoidot

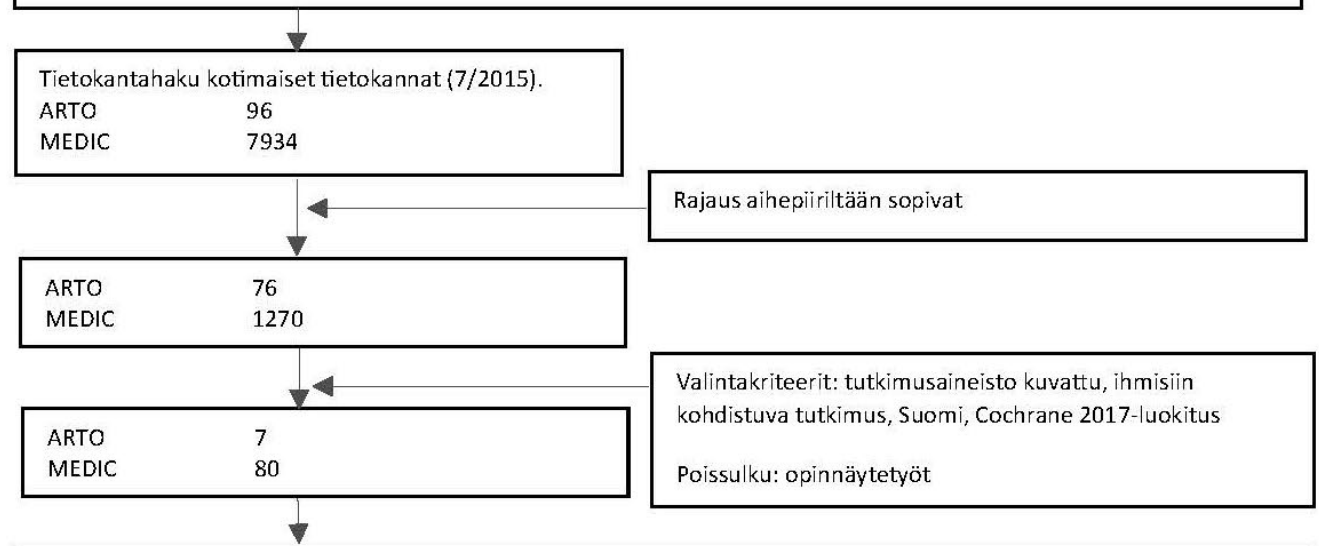

VAIHE 2. Hakusana: complementary therapies

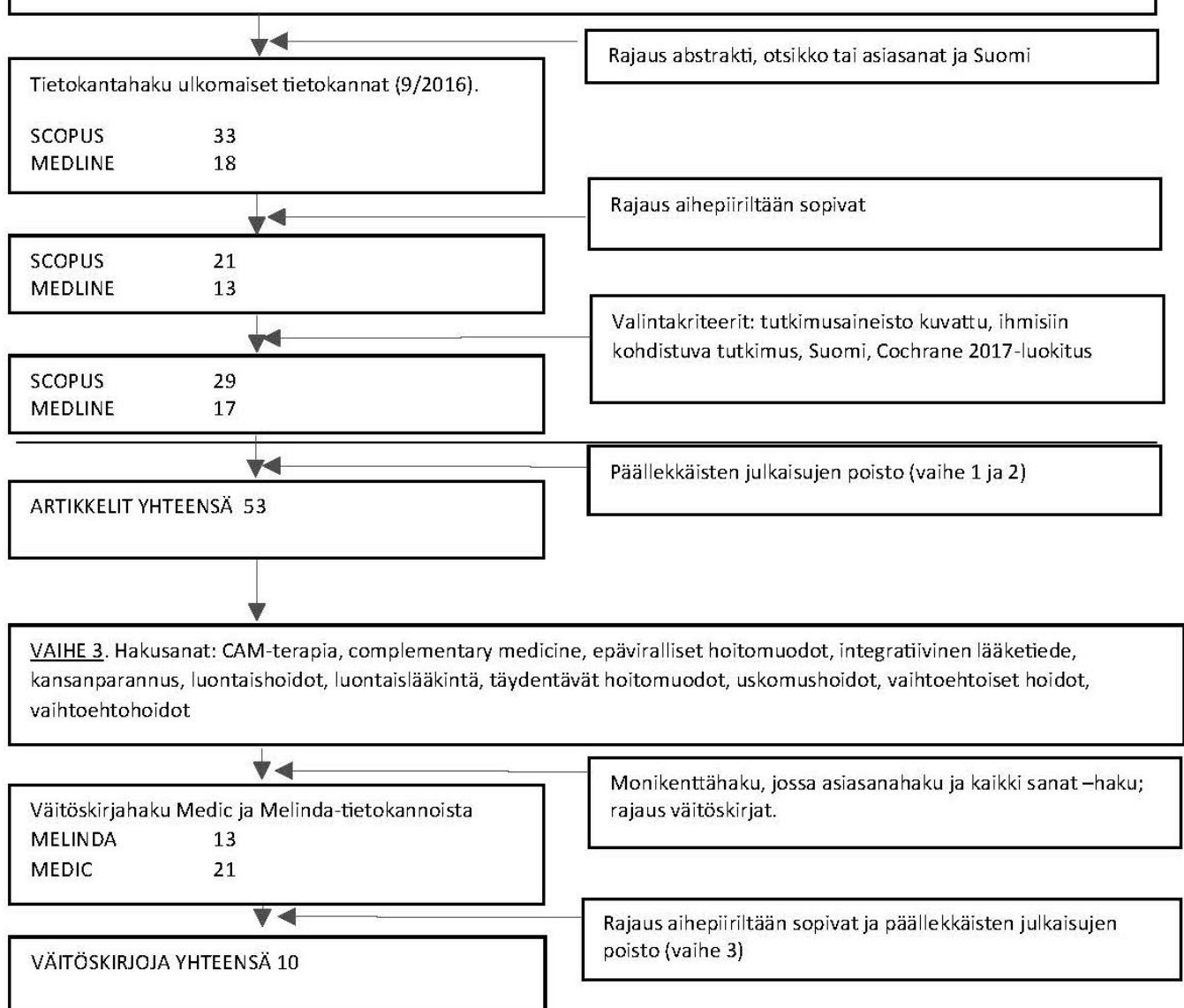


Taulukko 1. Suomalaista CAM-tutkimusta koskevien, vuosina 1980-2014 julkaistujen artikkeleiden ja väitöskirjojen analyysia ohjanneet kysymykset.

\begin{tabular}{|ll|}
\hline Analyysin teema & Analyysikysymykset \\
\hline 1. Tutkimuksissa mainitut hoidot & Mitä täydentäviä ja vaihtoehtoisia hoitoja tutkimus koskee? \\
\hline $\begin{array}{l}\text { 2. Tutkimuksen kohteet ja } \\
\text { tutkimuksen toteutus }\end{array}$ & Mikä on tutkimuksen kohde tai keskeinen teema? \\
& Mihin ihmisryhmiin tutkimus on kohdistunut? \\
& Mitä lähestymistapoja ja tutkimusotteita tutkimuksessa on käytetty? \\
& Millaisia laadullisia (haastattelu, kirjallisuuskatsaus, havainnointi) tai \\
& määrälisiä (kysely, kontrolloitu koe, kliininen testi) tutkimusmenetelmiä \\
tutkimuksessa on sovellettu?
\end{tabular}

Aineistosta selvitettiin tutkimuksen perustiedot (tekijä/t ja julkaisuvuosi), minkä jälkeen aineisto jaettiin analysoitavaksi artikkelin kirjoittajien kesken. Aineiston sisällönanalyysiä ohjaavat kysymykset on koottu taulukkoon 1.

\section{AINEISTON RAJOITUKSET}

Katsauksen ulkopuolelle jäi suuri joukko tieteellisissä lehdissä julkaistuja katsausartikkeleita, joissa ei ollut kuvattu tutkimusaineiston muodostumista tai tutkimuksen toteutusta. Esimerkiksi katsausartikkeli Laiho ym. (43) on synteesi kirjallisuudesta perustuen asiantuntijoiden arvioon. Myös ammatilliset julkaisut, mielipidekirjoitukset ja ulkomaita koskevat suomalaisten tutkimukset jäivät katsauksemme ulkopuolelle. Analyysin ulkopuolelle on jäänyt myös suomalaisten CAM-hoitojen käyttöä ja asenteita koskevan väestötutkimuksen perusraportti, josta ei ole tehty tieteellistä julkaisua (40) sekä selvitysluonteiset, ilman alkuperäisaineistoa laaditut raportit (9).

Käyttämiemme hakusanojen vuoksi katsauksen ulkopuolelle jäivät musiikki-, taide- ja draamaterapiat sekä erilaiset mindfulness -menetelmät, vaikka meditaatio luetaankin CAM-hoidoksi $(16,18)$. Vitamiineja ja hivenaineita koskevat tutkimukset tulivat hauissa mukaan vain, mikäli julkaisun otsikossa, abstraktissa tai asiasanoissa mainittiin käyttämiämme hakusanoja.

Vitamiinien, hivenaineiden ja ravintolisien tutkimukset ovat esimerkkejä CAM-hoitojen ja virallisten hoitojen liukuvasta ja ajankulussa muuttuvasta rajasta. Vitamiinit ovat jo vuosikymmenien aikana yleistyneet arkikäytössä ja osasta on virallisia ravintosuosituksia. Myöskään tutkijat eivät useinkaan miellä niitä CAM-hoidoiksi. Erilliset vitamiinitutkimukset eivät tulleet aineistoomme mukaan. Tutkijat eivät välttämättä käytä CAM-termejä tutkimusten yläkäsitteinä ja asiasanoina (5). Sama koskee myös kansan- ja perinneparannusta. Aineistomme ulkopuolelle on myös jäänyt valintakriteerit täyttäviä kansanparannustutkimuksia, esimerkiksi vuonna 2017 julkaistussa koosteessa (41) mainittuja. (Liite 1). Lisäksi aineistoa olisi voitu täydentää ja tarkistaa ottamalla huomioon mukaan valikoituneiden lähteiden lähdeviitteet.

Yleistermejä käytimme, koska tavoitteena oli löytää mahdollisimman kattavasti suomalaista CAM-tutkimusta. Yksittäisten hoitomuotojen nimityksillä (esimerkiksi akupunktio, antroposofinen lääkintä tai aromaterapia) haku ei ollut mahdollista, koska termien määrä olisi paisunut nyt käytetyistä yhdestätoista yli kahteensataan. Tekemistämme rajauksista huolimatta hakutermien valinta osoittautui haastavaksi, sillä samoilla käsitteillä löytyi hyvin erilaisia sisältöjä. Esimerkiksi Medic-tietokannasta saimme artikkeleita otsikoilla "Vaikean skolioosin hoito" ja "Psyykenlääkkeiden sudenkuopat".

\section{TULOKSET}

\section{AINEISTON KUVAUS}

Aineisto kattaa ajanjakson 1980-2014. Taulukossa 2 on esitetty artikkelien ja väitöskirjojen määrät vuosikymmenittäin. 
Taulukko 2. Tutkimusaineistoon sisältyneiden, CAM-hoitoja käsittelevien, vuosina 1980-2014 julkaistujen tutkimusartikkeleiden ( $\mathrm{N}=53$ ) ja väitöskirjojen $(\mathrm{N}=12)$ määrä vuosikymmenittäin.

\begin{tabular}{|lccc|}
\hline Vuodet & Artikkelit & Väitöskirjat & Yhteensä \\
\hline 1980-1989 & 12 & 3 & 15 \\
$1990-1999$ & 15 & 3 & 18 \\
2000-2009 & 18 & 3 & 21 \\
2010-2014 & 8 & 3 & 11 \\
\hline Yhteensä & 53 & 12 & 65 \\
\hline
\end{tabular}

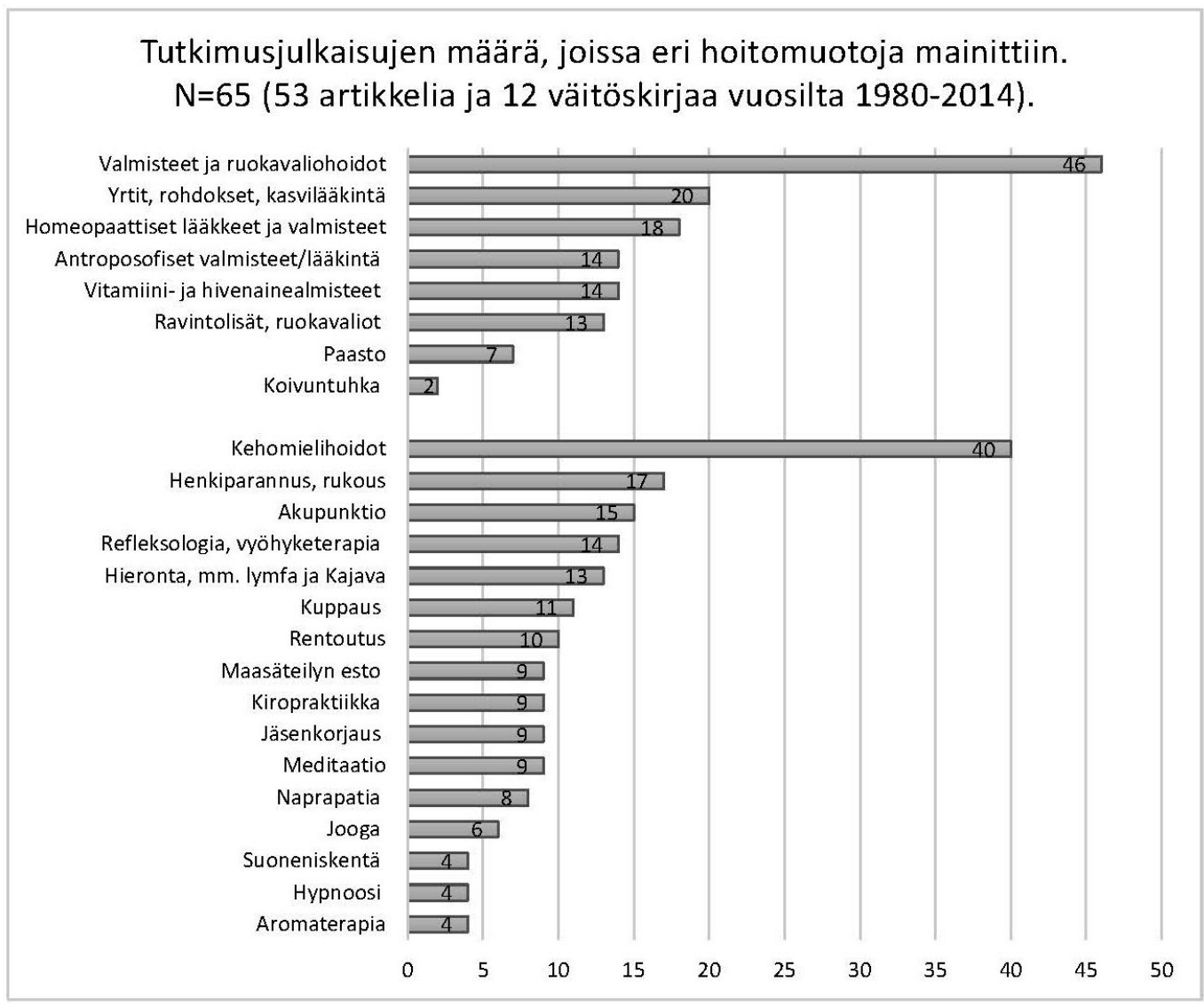

Kuvio 2. CAM-hoitoja käsittelevissä tutkimusjulkaisuissa vuosina 1980-2014 useammin kuin yhden kerran mainitut CAM-hoidot. Pääluokkien "Valmisteet ja ruokavaliohoidot" ja "Kehomielihoidot" alla olevat palkit kuvaavat julkaisujen määrää, joissa k.o. hoitomuoto on mainittu.

Huom.: Kuvion 2 hoitojen lisäksi vähintään yhdessä julkaisussa mainittiin joku tai joitakin seuraavista: avantouinti, Ayurveda, energiahoidot, heiluri, hydroterapia, kivi-, väri-, keskustelu- tai immunoterapia, käsilläparantaminen, koivunsiitepölyhunaja, mekaaninen hoito (lapamadon hoitotavat), porkkana, nikamakäsittely, rebalancing, reikihoito, tai chi, terapeuttinen kosketus ja rekabernaatio (asennetutkimusta varten keksitty käsite).

Valtaosa julkaisuista käsitteli samanaikaisesti useita hoitomuotoja. Niissä ei siis tutkittu yksittäisiä valmisteita, kehomielihoitoja tai hoitojärjestelmiä erikseen, vaan hoitoja käsiteltiin yhtenä kokonaisuutena, jossa CAM-ilmiötä kuvailtiin listaamalla erilaisia hoitomuotoja. Yksittäiseen hoitomuotoon kohdistuvista 15 artikkelista 7 käsitteli jäsenkorjausta, 2 koivuntuhkaa ja muiden aiheita olivat kuppaus, vyöhyketerapia, kansanparannus, koivunsiitepölyhunaja, suolahuone ja fysioakustinen tuoli. Väitöskirjoista neljä käsitteli yksittäistä hoitomuotoa, jotka olivat akupunktio, paasto, homeopatia ja kuppaus.

Kuviossa 2 on esitetty julkaisuissa mainittuja hoitomuotoja. Niistä useimmin mainittiin erilaisia syötäviä ja juotavia valmisteita (46 julkai- 
Taulukko 3. Suomalaista CAM-tutkimusta käsittelevien julkaisujen määrä julkaisuissa mainittujen kirjoittajien organisaatiotaustan mukaan. $\mathrm{N}=65$ (53 artikkelia ja 12 väitöskirjaa vuosilta 1980-2014)

\begin{tabular}{|lc|}
\hline Artikkelissa mainittu organisaatio & Julkaisujen määrä \\
\hline Helsingin yliopisto & 14 \\
Kuopion (Itä-Suomen) yliopisto & 17 \\
Oulun yliopisto & 7 \\
Jyväskylän yliopisto & 7 \\
Turun yliopisto & 7 \\
Tampereen yliopisto & 1 \\
Aluesairaala & 1 \\
Yliopistosairaala & 18 \\
Tutkimuslaitos & 10 \\
Muu tutkimus- tai asiantuntijaorganisaatio* & 15 \\
CAM organisaatio & 4 \\
Apteekki & 1 \\
Ulkomainen taho & 3 \\
Yritys & 1 \\
& \\
Väitöskirjan yliopisto & \\
Helsingin yliopisto & \\
Kuopion (Itä-Suomen) yliopisto & 2 \\
Oulun yliopisto & 2 \\
Jyväskylän yliopisto & 2 \\
Turun yliopisto & 1 \\
Tampereen yliopisto & 1 \\
\hline
\end{tabular}

"Lääkäriliitto, lääkintöhallitus, kela, sosiaali- ja terveyshallitus, terveyden edistämisen keskus, syöpäyhdistys, Suomen kuluttajaliitto, Suomen potilasliitto, Kuumat aallot -liike, Allergia- ja astmaliitto, Stakes, Kansanterveyslaitos

sussa), kuten siemen-, yrtti- ja kasvivalmisteet, rohdosvalmisteet, yhdistelmätuotteet, luontaistuotteet, ravintolisät, vitamiinit, vitamiininkaltaiset valmisteet, probiootit, pii- ja levävalmisteet, mineraalit, lääkkeenomaiset tuotteet ja aineet, luontaistuotteet, luonnonlääkkeet, vaihtoehtolääkkeet (alternative medicines), laksatiivit, kiwitabletit, koivuntuhkalipeä, kasviöljyt, kalkkivalmisteet, kalaöljyt, öljyhapot, homeopaattiset lääkkeet, helokkiöljy, hainevätabletit, ginseng, fluoritabletit, elintarvikkeet, joilla lääkkeenkaltainen valmistemuoto, diureetit, antioksidantit, antroposofinen lääkintä ja valmisteet, antioksidanttihoidot ja elävä ravinto. Kehomielihoitoja mainittiin 40 tutkimuksessa. Yleisimmin olivat esillä henkiparannus, akupunktio, vyöhyketerapia ja hieronta.

CAM-tutkimusta on tehty eniten lääketieteen, terveystieteiden ja sosiologian aloilla. Terveystieteistä on valmistunut neljä $(\mathrm{A}, \mathrm{B}, \mathrm{D}, \mathrm{L})$, yhteiskuntatieteistä kolme $(\mathrm{G}, \mathrm{H}, \mathrm{K})$, hoitotieteestä (E, I) ja humanistisista tieteistä (F, J) kummastakin kaksi väitöskirjaa. Yksi edustaa hammaslää- ketiedettä (C). Väitöskirjojen aineistonkeruussa on tehty yhteistyötä eri organisaatioiden (kuten yliopistosairaala, aluesairaala, kunnat, väestörekisterikeskus, perinnearkisto tai kansanopisto) kanssa. Tutkimusartikkeleista vain kahdeksassa ei ollut yliopistoa mukana ollenkaan. Eniten artikkelin tekijöitä oli Kuopion tai Itä-Suomen, toiseksi eniten Helsingin yliopistosta. Artikkelien tekijöiden edustamat organisaatiot on listattu taulukossa 3.

Valtaosassa artikkeleista rahoittajaa ei mainittu. Ilmoitettuja rahoittajia olivat yliopistot, Suomen Akatemia, Raha-automaattiyhdistys ja useat säätiöt. Artikkeleissa rahoittajina mainittiin myös Kela, Tekes ja yritykset. Väitöskirjoista Suomen Akatemian rahoitus mainittiin kolmessa, yliopiston neljässä ja tutkijakoulun rahoitus kolmessa hankkeessa. Säätiörahoitus mainittiin yhdeksässä ja syöpäpotilaiden yhdistykset kahdessa väitöskirjassa. Suomen sairaanhoitajaliitto, Suomen hammaslääkäriseura ja yritys (Vogel Oy) mainittiin kukin yhdessä väitöskirjassa. 
Taulukko 4. CAM-hoitoja käsittelevien tutkimusartikkelien ( $\mathrm{N}=53)$ ja väitöskirjojen ( $\mathrm{N}=12)$ tutkimuskohteet vuosikymmenittäin vuodesta 1980 vuoteen 2014 .

\begin{tabular}{|c|c|c|c|c|c|}
\hline Tutkimuskohteet artikkeleissa & 1980-1989 & 1990-1999 & 2000-2009 & 2010-2014 & Yhteensä \\
\hline 1) Hoitojen vaikuttavuus ja käytettävyys & 1 & 1 & 6 & 2 & 10 \\
\hline 2) Hoitojen historia, kansanperinne & 4 & 0 & 1 & 0 & 5 \\
\hline $\begin{array}{l}\text { 3) Käytön yleisyys, käyttäjät ja heidän } \\
\text { kokemuksensa ja asenteensa }\end{array}$ & 5 & 10 & 7 & 5 & 27 \\
\hline $\begin{array}{l}\text { 4) Hoitohenkilökunnan asenteet tai } \\
\text { suhtautuminen }\end{array}$ & 1 & 4 & 3 & 1 & 9 \\
\hline $\begin{array}{l}\text { 5) CAM-ammattien tutkimus, tieteentutkimus, } \\
\text { hoitonäkemykset }\end{array}$ & 1 & 1 & 0 & 0 & 2 \\
\hline Yhteensä & 12 & 16 & 17 & 8 & 53 \\
\hline Tutkimuskohteet väitöskirjoissa & 1980-1989 & 1990-1999 & $2000-2009$ & $2010-2014$ & Yhteensä \\
\hline 1) Hoitojen vaikuttavuus ja käytettävyys & 1 & 1 & & & 2 \\
\hline 2) Hoitojen historia, kansanperinteet & 1 & 1 & & 1 & 3 \\
\hline $\begin{array}{l}\text { 3) Käytön yleisyys, käyttäjät ja heidän } \\
\text { kokemuksensa ja asenteensa }\end{array}$ & 1 & 1 & 2 & 1 & 5 \\
\hline $\begin{array}{l}\text { 4) Hoitohenkilökunnan asenteet tai } \\
\text { suhtautuminen }\end{array}$ & & & 1 & & 1 \\
\hline $\begin{array}{l}\text { 5) CAM-ammattien tutkimus, tieteentutkimus, } \\
\text { hoitonäkemykset }\end{array}$ & & & 1 & 1 & 2 \\
\hline Yhteensä & 3 & 3 & 4 & 3 & $13^{*}$ \\
\hline
\end{tabular}

*Määrä on 13, koska Liisa Salmenperän artikkeliväitöskirjan kooste koski selkeästi kahta kohdetta: potilaiden CAM-käyttöä ja hoitohenkilökunnan asenteita.

\section{CAM-TUTKIMUKSEN KOHTEET JA TUTKIMUSTULOKSET}

Jaoimme artikkelit ja väitöskirjat viiteen luokkaan tutkimuskohteen mukaan (taulukko 4). Lisäksi analysoimme tutkimuksen tuloksia ja päätelmiä.

\section{CAM-HOITOJEN VAIKUTTAVUUDEN JA KÄYTETTÄVYYDEN TUTKIMUS}

Hoitojen vaikuttavuutta ja käytettävyyttä koskevat aiheet keskittyivät jäsenkorjauksen (a3, a25, a28, a33), koivuntuhkalipeän (a35), vyöhyketerapian (a45), suolahuoneen (a31), koivunsiitepölyhunajan (a51) ja matalataajuisten ääniaaltojen (a53) vaikutustutkimukseen. Yhdessä artikkelissa selvitettiin lääkkeettömien hoitojen vaikuttavuutta syöpäkivun hoitoon (a7) ja yhdessä potilas-parantaja-suhteen vaikutuksia (a41). Väitöskirjoissa käsiteltiin paaston (E) ja akupunktion (C) vaikutuksia. Artikkeleita oli eniten 2000-luvun ensimmäisellä vuosikymmenellä, kun taas väitöskirjat oli tehty ennen vuosituhannen vaihdetta. Tutkimuksista kuusi oli satunnaistettua kliinistä koetta, yksi eläinkoe (rottakokeella testattu koivuntuhkalipeän käytettävyyttä ihmisillä) ja yksi yksittäisen potilaan hoidon tehon kuvaus. Kahdessa tutkimuksessa oli tehty sekä havainnointia että kysely.
Hoitojen vaikuttavuuden ja käytettävyyden tutkimuksessa osoitettiin perinteinen suomalainen jäsenkorjaus kliinisissä kokeissa (a25, a28), potilaita haastattelemalla ja havainnoimalla (a3, a33) tehokkaaksi ja toimivaksi hoitomuodoksi kroonisten niskakipujen lievittäjänä. Akupunktiosta todettiin voivan olla hyötyä subjektiivisten ja kliinisesti havaittujen oireiden hoidossa potilailla, joilla on leukanivelen toimintahäiriöitä (C). Vyöhyketerapiasta tehdyn pilottitutkimuksen (a45) mukaan hoito näytti laskevan verenpainetta ja stressitasoa. Suolahuoneen ja koivunsiitepölyhunajan vaikutuksista astma- ja allergiaoireiden lievittymiseen saatiin jonkin verran näyttöä (a31, a51), samoin matalataajuisesta ääniterapiaohjelmasta huonokuntoisten vanhusten toimintakyvyn ja hyvinvoinnin paranemiseen (a53) ja lääkkeettömistä hoidoista syöpäkivun lievityksessä (a7). Sen sijaan kansanomaisena syövänhoitomuotona käytetty koivuntuhka osoittautui eläinkokeisiin nojaten tehottomaksi (a35).

CAM-hoitojen vaikutustutkimus antaa tämän katsauksen aineiston perusteella viitteitä yksittäisten CAM-hoitojen hyödyistä pikemmin kuin niiden haitoista. Väestötason päätelmiä ei kuitenkaan voi tehdä, koska ensiksikin aineis- 
tomme vaikutustututkimuksissa on rajoitteita aineistojen ja menetelmien osalta, toiseksi, koska tutkimus on hyvin vähäistä. Kolmanneksi, aineistossamme ei käsitelty kattavasti niin sanotun plasebovaikutuksen merkitystä.

\section{CAM-HOITOJEN HISTORIAN JA KANSANPERINTEEN TUTKIMUS}

Hoitojen historian tutkimus kohdistui perinneparannuksen menetelmäkuvauksiin. Tutkittuja hoitoperinteitä olivat artikkeleissa jäsenkorjaus (a4, a5), saamelainen kansanparannus (a13) ja kuppaus (a20). Myös syöpänarratiiveja analysoitiin arkistoaineiston perusteella (a26). Väitöskirjatutkimukset kohdistuivat syövän (A) ja lapamadon (L) hoitomuotoihin sekä kuppaukseen (J). Tutkimusmenetelminä käytettiin kvalitatiivista haastattelua, narratiivista analyysia ja monimetodista tutkimusotetta.

Hoitojen historiaa ja perinteisiä hoitotapoja selvittelevä tapaustutkimus jäsenkorjauksesta viittasi siihen, että lääkäreiden ja jäsenkorjaajien yhteistyö voisi tuottaa taloudellisia säästöjä ja olisi potilaan kannalta tehokkaampaa kuin kummankin toimiminen erillisinä $(\mathrm{a} 4, \mathrm{a} 5)$. Saamelaisesta kansanparannuksesta todettiin, että saamelaiset yleensä luottivat parantajiinsa, jotka korostivat potilaan uskon merkitystä hoidon onnistumisessa. Näin ollen tutkimuksessa pääteltiin, että hoidon teho oli ilmeisesti plasebon vaikutusta. (a13).

\section{CAM-HOITOJEN KÄYTÖN YLEISYYDEN JA RÄYTTÄJÄRYHMIEN TUTKIMUS}

CAM-hoitojen käytön yleisyydestä, käyttäjäryhmistä tai heidän näkemyksistään ja asenteistaan julkaistiin lukumääräisesti eniten artikkeleita ja väitöskirjoja. Erityisinä käyttäjäryhminä tutkittiin lapsia (a2, a10, a12, a18, a19, a29, a50), syöpäpotilaita (a15, a16, a29, a52), naisia (a30, a49), mielenterveyspotilaita (a24), opiskelijoita (a1), luontaistuotekaupan asiakkaita (a47) ja vaatetusalan työntekijöitä (a34). Yksi väitöskirja tutki CAM-terapeuttien asiakkaita $(\mathrm{G})$, terapioina olivat vyöhyketerapia, Kajavahieronta, Rosen-menetelmä ja Rebalancing-kehoterapia, yksi paastokurssille osallistuneita (E) ja yksi syöpäpotilaita (I). Tutkimukset olivat pääosin kvantitatiivisia kyselytutkimuksia. CAM-käytön yleisyyttä koko suomalaisväestössä on tutkittu sosiaali- ja terveysministeriön rahoittamana ja Tilastokeskuksen toteuttamana haastattelututkimuksena vuosina 1982 ja 1992. Aineistomme viisi artikkelia (a39-a43) raportoivat näiden kyselyjen tuloksia.

Käytön yleisyyttä, käyttäjiä ja heidän asenteitaan ja näkemyksiään alettiin Suomessa tutkia 1970-luvun lopulla. Perinteiset eli kansanomaiset hoidot tarkoittivat hierontaa, nikamankäsittelyä, kuppausta ja muuta kansanparannusta ja uudistehoidot vieraista kulttuureista tulleita hoitomuotoja tai kaupallisesti tuotettuja valmisteita: akupunktio, jooga, rentoutus, meditaatio, hypnoosi, luontaistuotteet, luonnonlääkkeet, dieetti- ja paastohoidot. Koko maassa hieronta oli yleisimmin käytetty kansanomainen hoitomuoto, Pohjanmaalla käytettiin paljon jäsenkorjausta. (a21, a27).

Vuonna 1992 toteutetun väestötutkimuksen mukaan jotakin epävirallista hoitomuotoa (perinteisiä tai uudistehoitoja) oli viimeksi kuluneen vuoden aikana käyttänyt lähes puolet (46\%) aikuisista. Perinteisiä hoitoja oli käyttänyt silloin tällöin $25 \%$, uudistehoitoja $33 \%$ ja luonnonlääkkeitä $21 \%$ tutkituista. Lähes kaikki käyttäjät, joista valtaosa oli kokenut saaneensa apua vaivoihinsa, käyttivät samanaikaisesti myös virallisia terveyspalveluja. Suosituimmat CAM-hoitomuodot olivat hieronta, kiropraktiikka, naprapatia ja vyöhyketerapia. Noin $13 \%$ oli hoitojen suurkuluttajia. (a43). 2000-luvun alussa käyttäjiä oli noin $35 \%$ (a24) ja $28 \%$ tutkituista (a11). Jälkimmäisessä tutkimuksessa (a11) eivät olleet mukana hieronta, kiropratiikka, naprapatia, akupunktio ja vyöhyketerapia. Tyypillinen käyttäjä oli melko korkeasti koulutettu, naimisissa tai parisuhteessa oleva, työssä käyvä, melko hyvätuloinen ja työkykyä alentavasta somaattisesta pitkäaikaissairaudesta tai vammasta kärsivä nainen (a24).

Väestötutkimusten päätelminä todettiin, että suomalaiset hyväksyvät koululääketieteen ja CAM-hoidot toisiaan täydentävinä. Jatkotutkimuksiksi ehdotettiin CAM-hoitojen suurkuluttajien sekä käytön syiden tutkimista sekä sen selvittämistä, perustuuko hoitojen runsas käyttö terveyden ylläpitämiseen, sairauden hoitoon vai muuhun tarpeeseen. (a39-a43).

Vaatetusalan naistyöntekijöiden CAM-käytön pääteltiin liittyvän terveystietoisuuden voimistumiseen. Käyttöä ei selittänyt tyytymättömyys virallisiin terveyspalveluihin, sillä näihin tyytyväiset turvautuivat myös CAM-hoitoihin 
keskimääräistä useammin. (a34). Raskauden aikainen luontaislääkkeiden käyttö oli vähäistä (alle $4 \%$ ), tuotteet olivat enimmäkseen haitattomia eikä niitä käytetty korvaamaan tavanomaisia lääkkeitä (a30). Vaihdevuosioireisiin noin $11 \%$ naisista käytti vaihtoehtolääkkeitä (a49).

Osana lääkkeiden käyttötutkimusta tehdyssä väestökyselyssä kävi ilmi, että CAM-tuotteita käytti vanhempien mukaan $11 \%$ lapsista. Vanhemmat kuvasivat hoitomuotojen tuovan helpotusta lapsen oireisiin pikemminkin kuin valittivat niiden tehottomuutta. Tutkimuksessa, jossa luonnonlääkkeiksi luettiin myös vitamiinit ja hivenaineet, kävi ilmi, että lähes kolmannes vanhemmista oli antanut CAM-tuotteita lapsilleen kahden viimeksi kuluneen päivän aikana. Tuotteita käytettiin yleensä täydennyksenä muuhun hoitoon tai terveyden edistämiseksi. Koulutetut, parempituloiset ja naiset käyttävät niitä lapsilleen eniten (a2, a12, a18). Sairaalahoitoon tulleista allergisista lapsista $17 \%$ käytti tai oli kokeillut luonnonlääkkeitä (a10) ja ärtyneen suolen oireyhtymästä ja niveltulehduksesta kärsivistä lapsista $48 \%$ käytti säännöllisesti probiootteja, monivitamiineja, mineraaleja ja hivenaineita (a50). Yhteistä CAM-hoitoja käyttävien lasten vanhemmille oli, että heillä oli negatiivisempi suhtautuminen lääkkeisiin kuin ei-käyttäjillä (a2, a12)

Syöpäpotilaiden CAM-hoitojen käyttö oli varsin yleistä 1980-luvun alussa. Niitä käytti $30 \%$ mies- ja $55 \%$ naispotilaista. Heistä $72 \%$ käytti tai oli käyttänyt koivuntuhkaa (A, a48). 1990-luvun potilaskyselyn mukaan $30 \%$ tutkituista rintasyöpä- ja $28 \%$ eturauhassyöpäpotilaista olivat sairastuttuaan käyttäneet jotakin CAM-hoitoa (a16). Puolet potilaista uskoi, että syöpäpotilaat voivat hyötyä CAM-hoidoista, vaikka he eivät ajatelletkaan näiden hoitojen parantavan itse syöpää. Valtaosa $(80 \%)$ vastaajista suhtautui myönteisesti siihen, että luotettavat CAM-hoitajat rekisteröitäisiin virallisesti. Vain joka neljäs kertoi lääkärille CAM-käytöstään. (a15). Leukemiaa sairastavien lasten perheissä käytettiin selvästi enemmän kaikkia CAM-tuotteita (vitamiineja, hivenaineita ja muita tuotteita kuten hainrusto- ja helokkitabletteja) kuin vertailuperheissä. Mikään tutkimusperhe ei luopunut tavanomaisesta hoidosta käyttäessään CAM-tuotteita. (a29).

Opiskelijatutkimuksen tulokset CAM-hoitojen käytön psykologisista tekijöistä vahvistivat hypoteesin, että maagiset ruoka- ja terveysuskomukset, syömishäiriöt, kasvissyönti, naissukupuoli ja myönteisyys vaihtoehtohoitoihin sekä intuitiivinen ajattelu olivat yhteydessä toisiinsa (a1). Toisessa tutkimuksessa CAM-uskomukset selittyivät intuitiivisella ajattelulla, paranormaaleilla uskomuksilla ja fysikaalisia, biologisia ja mentaalisia ilmiöitä koskevalla sekaannuksella paremmin kuin tavanomaisilla sosioekonomisilla tekijöillä. Tämä ontologinen sekaannus tarkoitti, että CAM-myönteisen ajattelun kategoriavirhe johti sekoittamaan keskenään fysikaalisia, biologisia ja psykologisia ilmiöitä. Tällaisen intuitiivisen ajattelun katsottiin voivan johtaa CAM-hoitojen käyttäjää harhaan. (a11).

\section{HOITOHENKILÖKUNNAN ASENTEIDEN JA SUHTAUTUMISEN TUTKIMUS}

Hoitohenkilökunnan asenteiden tai suhtautumisen tutkimuksen kohteena olivat useimmiten lääkärit. Lääkärien näkemyksiä on selvitetty Suomen Lääkäriliiton kolmessa tutkimuksessa (a8, a9, a23) sekä kolmessa muussa tutkimuksessa (a6, a17, a44). Syövänhoitotyötä tekevien sairaanhoitajien asenteita ja käsityksiä on selvitetty yhdessä väitöskirjassa (I) ja kahdessa artikkelissa (a14, a38). Myös apteekkarien käsityksiä on tutkittu (a46). Kaikki edellä mainitut olivat kyselytutkimuksia.

Hoitohenkilökunnan asenteet ja näkemykset CAM-hoidoista olivat jakautuneita. Lääkärien asenteet vaihtelivat hoitomuodosta toiseen. Myönteisintä suhtautuminen oli akupunktioon, kiropraktiikkaan ja naprapatiaan, joita 26-37\% lääkäreistä voisi harkita laajempaan käyttöönkin. Kielteisimmin suhtauduttiin henkiparannukseen. Sitä piti petoksena $62-75 \%$ kyselyyn vastanneista. CAM-hoitojen ero tavanomaisiin lääketieteellisiin hoitoihin tehtiin 1980-luvun artikkeleissa käsiteparilla "rationaalinen-irrationaalinen" ja vuonna 2012 "näyttöön perustuva - epätieteellinen uskomus” (a8, a9, a23). Syöpälääkäreistä yli puolet hyväksyi epäortodoksiset hoitomuodot terminaalivaiheen potilaille, jos potilaat niitä toivoivat (a6). Huolimatta skeptisyydestä, yli puolet onkologeista uskoi CAM-hoitojen vähentävän stressiä ja ahdistusta ja saman verran oli niitä, jotka eivät omasta mielestään tienneet CAM-hoidoista tarpeeksi (a17).

Syöpäosaston sairaanhoitajat suhtautuivat CAM-hoitoihin yhtäältä kielteisesti ja pitivät 
niitä hölynpölynä ja potilaiden parantumiskokemuksia liioiteltuina, mutta toisaalta katsoivat, että CAM-hoidot voisivat täydentää tavanomaista hoitamista (a14). Suurin osa oli valmiita keskustelemaan potilaiden kanssa CAM-hoitojen käytöstä. Pohjaksi hoitajat kaipasivat koulutusta, tietoa tutkimustuloksista, vaikutuksista, hyödyistä ja haitoista. (a38). Apteekkarit kokivat, että he eivät pysty antamaan CAM-valmisteista samantasoista tietoa asiakkaille kuin mihin he pystyvät lääkevalmisteista (a46).

\section{CAM-AMMATTIEN TUTKIMUS, TIETEENTUTKIMUS JA HOITONÄKEMYSTEN TUTKIMUS}

CAM-ammattien tutkimusta ei Suomessa ole tehty. Aineistossamme oli vain yksi väitöskirja homeopaateista $(\mathrm{H})$, jossa painopiste oli kuitenkin potilaan ja hoitajan vuorovaikutuksessa, ei homeopaatin ammatillisuudessa. Myöskään terveydenhuoltohenkilökunnan ja CAM-hoitajien välisen vuorovaikutuksen tutkimusta ei ollut. Tieteentutkimusta edusti yksi väitöskirja (K), jossa tutkittiin paaston ja terapeuttisen kosketuksen ympärille syntyneitä kiistoja 1990-luvulla. CAM-hoitonäkemyksiä käsiteltiin kahdessa artikkelissa (a22, a37), joissa tarkasteltiin opillisia erityispiirteitä, sairauksien selitysteorioita, hoitosuhdetta ja alan yhteiskuntatieteellistä tutkimusta. Käytetyt tutkimusmenetelmät olivat keskustelunanalyysi, retorinen analyysi ja laadullinen sisällönanalyysi.

\section{POHDINTA}

Katsausartikkelimme kartoittaa tutkimusta CAMhoidoista tuottaen ensimmäistä kertaa yleiskuvaa siitä, millainen tietopohja maassamme on käytettävissä erilaisista vaihtoehtoisista tavoista hoitaa terveyttä ja edistää hyvinvointia. Katsaus tuottaakin mahdollisuuksia alkaa arvioida sitä, missä määrin kansalaisilla on saatavilla tietoa hoidoista, joita käyttää varsin moni, sekä siitä, millaista tuo tieto on sisällöltään. Se antaa suuntaa siitä, millaisen tietopohjan varassa ihmiset tekevät päätöksiä mennä CAM-hoitoihin julkisesti rahoitettujen hoitojen lisänä tai sijasta. Maassamme näyttää katsauksemme perusteella olevan vain vähän tutkimustietoa CAM-hoidoista. Tosin joidenkin yksittäisten hoitojen - kuten esimerkiksi homeopatian tai kiinalaisen lääkinnän - osalta saattaisi tutkimusta löytyä enemmän, jos hakutermeiksi valittaisiin yksittäisiä hoitomuotoja.
CAM-hoitoihin liittyvän tietopohjan kartoittaminen on ajankohtaista siksi, että sosiaali- ja terveydenhuoltoon suunnitellaan maassamme tällä hetkellä laajoja uudistuksia. Suuri osa kansalaisista on muutosten hetkellä muun kuin suomenkielisen tutkimustiedon varassa erilaisten mediassa, sosiaalisessa mediassa, katukuvassa ja terveyspalvelujen sisällä markkinoitujen hoitomuotojen kanssa.

Katsauksessamme käsitellyt tutkimukset antavat taustaa ymmärtää, missä määrin ja mistä syistä kansalaiset käyttävät vapauttaan valita CAM-hoitoja. Tavoitimme CAM-hoitojen käyttöä koskevaa tutkimusta laajasti, joten katsauksemme tarjoaa terveydenhuollon ammattilaisille läpileikkauksen tutkimuksesta, jota voi hyödyntää etsiessään tietoa CAM-hoitojen käytön yleisyydestä maassamme tai tiettyjen erityisryhmien, kuten syöpäpotilaiden tai lasten CAM-hoitojen käytöstä. Terveydenhuollon ammattilaisten on hyvä tietää, että Suomessa tuotettua tietoa CAM-hoitojen tehokkuudesta on hyvin vähän, joten moni kansalainen saattaa valitessaan CAM-hoitoja tukeutua ulkomaisiin tietolähteisiin.

Viimeisimmässä sosiaali- ja terveysministeriön CAM-hoitoja koskevassa selvityksessä korostettiin CAM-tutkimustiedon merkitystä ja CAM-tietopankin perustamista (9). CAM-hoitojen sääntelyä pohdittaessa ajantasainen tieto kansalaisten asennoitumisesta terveydenhuollon palveluihin ja erilaisiin hoitoihin on mielestämme tärkeää. Terveystutkijoille ja muille tutkijoille artikkelimme jäsentää CAM-alan terminologiaa ja siihen liittyviä tiedonhaun kysymyksiä. CAM-alan hakusanojen käyttö on Suomessa vakiintumatonta, sillä hakusanoilla löytyi runsaasti artikkeleita, jotka eivät liity lainkaan CAMaihepiiriin.

Jo artikkelimme aineistonkeruuvaiheessa paljastui käsitteiden ja asiasanojen kirjavuus. Analysoimissamme tutkimusraporteissa käytetyt CAM-hoitojen määritelmät olivat vaihtelevia eikä kansainvälisiä luokituksia sovellettu. CAM-hoitoihin saatettiin sisällyttää niin avantouinti, porkkana, henkiparannus kuin hierontakin. Tämä heijastelee sitä, että maassamme ei ole järjestelmää, joka kirjaisi tai listaisi käytettyjä hoitomuotoja. Finto-asiasanastopalvelu ehdottaa CAM-hoidoille yläkäsitettä 'vaihtoehtolääkintä', mutta se ei tavoittanut alkuperäistutki- 
muksia (Medic-tietokannassa ei yhtään osumaa, Arto-tietokannassa lähinnä keskusteluartikkeleita). Termi 'uskomuslääkintä' osoittautui hyödyttömäksi etsittäessä CAM-tutkimusta, koska termiä käytettiin keskusteluartikkeleissa, mutta ei tutkimusraporteissa. Uskomushoito-termiä onkin aiemmin kritisoitu vastakkainasettelun lisäämisestä $(3,44-46)$ sekä sopimattomuudesta tutkimuksen käyttöön (4-6).

Katsauksemme kartoittaa, miten CAM-tutkimus Suomessa on kehittynyt ja millaista tutkimusta maassamme on CAM-hoidoista tehty. Tämäntyyppistä tutkimusta on aiemmin tehty eri maissa lähinnä laajojen kansainvälisten tietokantojen avulla $(36,38)$. Tällaisia tietokantoja ovat esimerkiksi Web of Science, Science Citation Index Expanded ja Medline, jotka painottavat englannin kieltä ja kansainvälistä julkaisemista. Artikkelimme tuo esiin CAM-tutkimusta suomalaisista tietokannoista ja erityyppisillä foorumeil- la, joita ei voitaisi tavoittaa vain kansainvälisiä tietokantoja hyödyntämällä.

Yhteiskunnallisesti CAM-tutkimustiedon kokoaminen auttaa ymmärtämään CAM-hoidoista käytäviä kiistoja ja vastakkainasetteluja niiden ympärillä. Artikkelimme taustoittaakin kiistelyä CAM-hoitojen hyödyistä ja haitoista uudella tavalla. Terveyden hoitaminen yleensä ja CAM-hoitojen suosio erityisesti koskee laajoja kulttuurisia, yhteisöllisiä ja yhteiskunnallisia kysymyksiä, joissa ei voida sivuuttaa parantamisen monimuotoisuutta ja muuttuvia kulttuurisia käsityksiä erilaisista terapeuttisista käytännöistä $(3,8,47-48)$.

\section{KIRJOITTAJIEN KONTRIBUUTIOT:}

Aineiston keruusta vastasivat Pia Vuolanto ja Minna Sorsa. Kaikki kirjoittajat osallistuivat tasapuolisesti aineiston analysointiin ja artikkelikäsikirjoituksen kirjoittamiseen.

\section{Vuolanto, P., Sorsa, M., Aarva, P., Helin, K. A review of Finnish CAM research. Sosiaalilääketieteellinen aikakauslehti - Journal of Social Medicine 20 I 8: 55: 243-259.}

This review article concerns Finnish research on complementary and alternative medicine (CAM). The aim of the article is to analyse what kind of CAM research has been conducted in Finland and what has this research been targeted at. The data consist of 53 research articles and $12 \mathrm{PhD}$ dissertations from years 1980-2014. The data was drawn from Finnish and international databases. Content analysis was used as a research method. CAM research was conducted especially during the 1990s and at the beginning of the 2000s. Most usually the studies were done within universities or in collaboration with them. A majority of publications dealt with CAM treatments as a whole and did not separate between different modalities. The studies considered herbal products, medicinal herbs, homeopathic and antroposophic medicines, diets and mind-body practices. Spiritual healing, acupuncture and reflexology were mentioned most often as mind-body practices.

We classified Finnish CAM research according to international classifications: 1) research on the impact and efficacy of CAM treatments, 2) research on the history and popular tradition of CAM treatments, 3) research on the prevalence and user groups of CAM treatments, 4) the attitudes and perceptions of health care personnel on CAM. We also found a fifth whole, although very little research was done on this in Finland: research on CAM professions, science studies and views of care. Most of the studies focused on the prevalence and the user types of CAM. According to these studies, one third of Finnish adults had used or tried some CAM treatments. Other research foci were the effects of CAM, the attitudes of healthcare personnel towards CAM and the history of CAM treatments. The effects of traditional manipulation were analysed most among studies of the impact of CAM treatments. The attitudes of medical practitioners and nurses toward CAM were mixed.

Keywords: complementary and alternative medicine, CAM, CAM research, content analysis, science studies

Saapunut 15.10.2017 Hyväksytty 06.2.2017 
(1) Kemppainen L, Kemppainen T, Salmenniemi $S$, ym. Use of complementary and alternative medicine in Europe: Health-related and sociodemographic determinants. Scand Pub Health. doi: 10.1177/1403494817733869 https://doi.org/10.1177/1403494817733869

(2) Alasuutari P. Tasavalta. Sodan jälkeisen Suomen kaudet ja trendit. Tampere: Vastapaino; 2017.

(3) Hokkanen M, Kananoja K. Kiistellyt tiet terveyteen. Parantamisen monimuotoisuus globaalihistoriassa. Helsinki: SKS; 2017. https://doi.org/10.21435/ht.273

(4) Hemilä H. Uskomushoito tarkoittaa eri asiaa kuin CAM. Suomen Lääkäril 2016;71:2404.

(5) Hemilä H. Vaihtoehto voi joskus perustua näyttöön. Suomen Lääkäril 2016;71:12981299.

(6) Hemmilä H. Luopukaamme termin uskomuslääkintä käytöstä. Duodecim 2007;123:2352.

(7) Vuolanto, P. Hyvän tieteen määrittely ja rajanvetokiistat. Kirjassa: Muhonen R, Puuska HM (toim.) Tutkimuksen kansallinen tehtävä. Tampere: Vastapaino; 2014, 259-270.

(8) Vuolanto, P. The incompatibility between social worlds in complementary and alternative Medicine. Kirjassa: Brosnan C., Vuolanto P, Brodin Danell JA (toim.) Complementary and alternative medicine: Knowledge production and social transformation. Palgrave MacMillan. (ilmestyy huhtikuussa 2018)

(9) Sosiaali- ja terveysministeriö. Vaihtoehtohoitojen sääntelyn tarve. Vaihtoehtohoitoja koskevan lainsäädännön tarpeita selvittäneen työryhmän raportti 2009. Luettu 20.2.2018. http://urn.fi/ URN:ISBN:978-952-00-2810-7

(10) Hietanen P. Vastakkainasettelujen aikaa. Suomen Lääkäril 2013;68:1313.

(11) Rautavaara J. Tiedä, kuka potilastasi hoitaa. Nuoren lääkärin blogi 17.3.2014. Luettu 20.2.2018. https://www.nly.fi/artikkeli/tiedakuka-potilastasi-hoitaa

(12) Ekholm V. Huuhaata vai vaikuttavaa hoitoa. Suomen tiedetoimittajain liitto. Luettu 20.2.2018. http://www.tiedetoimittajat.fi/ tiedetoimittaja/huuhaata-vai-vaikuttavaa-hoitoa/

(13) Pälve H. Vaihtoehtoiset hoidot eivät kuulu lääketieteeseen. Potilaan lääkärilehti 20.2.2018. http://www.potilaanlaakarilehti. fi/laakarit-ottavat-kantaa/laakariliitonpalve-vaihtoehtoiset-hoidot-eivat-kuululaaketieteeseen/

(14) Seppänen J, Kamaja M, Myllykangas M, Tuomainen T-P. CAM ei ole neutraali termi. Suomen Lääkäril 2016;71:2404-2405.

(15) Piela U. "Konsti elää kauwwan". Parantaminen Suomessa varhaismodernilta ajalta nykypäivään. Kirjassa Hokkanen M, Kananoja K (toim.) Kiistellyt tiet terveyteen. Parantamisen monimuotoisuus globaalihistoriassa. Helsinki: SKS; 2017, 83-129.
(16) Wieland LS, Manheimer E, Berman B. Development and classification of an operational definition of complementary and alternative medicine for the Cochrane collaboration. Altern Ther Health Med 2011;17:50-59.

(17) World Health Organization. Traditional medicine strategy 2014-2023. Geneva: World Health Organization; 2013.

(18) National Center for Complementary and Integrative Health. Types of Complementary Health Approaches 2017. Katsottu 20.2.2018. https://nccih.nih.gov/health/integrativehealth\#types

(19) Gale N. The sociology of traditional, complementary and alternative medicine. Sociol Comp 2014;8:805-822. https://doi.org/10.1111/soc4.12182

(20) Nissen N \& Manderson L. Researching alternative and coplementary therapies: Mapping the field. Medic Anthrop 2013;32:1-7. https://doi.org/10.1080/01459740.2012.718016

(21) Ernst E, Soo ML. Ayurvedic medicine: An overview of systematic reviews. Perfus 2010;23:168-170.

(22) Posadzki P, AlBedah AMN, Khalil MMK, ym. Complementary and alternative medicine for lowering blood lipid levels: A systematic review of systematic reviews. Complem Therap Med 2016;29:141-151. https://doi.org/10.1016/j.ctim.2016.09.019

(23) Alver BG, Fjell TI, Ryymin T. Vitenskap og varme hender. Den medisinske markedsplassen i Norge fra 1800 til i dag. Oslo: Scandinavian Academic Press; 2013.

(24) Lee-Treweek G, Heller T, Katz J, ym. (toim.) Perspectives on complementary and alternative medicine. Abingdon: Routledge; 2005.

(25) Gale N, McHale J. Introduction: Understanding CAM in the twenty-first century - the importance and challenge of multi-disciplinary perspectives. Kirjassa Gale N, McHale J (toim.) Routledge handbook of complementary and alternative medicine: Perspectives from social science and law. London: Routledge; 2015, 1-9.

(26) Sharma A. Medicine from the margins? Naturheilkunde from medical heterodoxy to the University of Berlin 1889-1920. Soc Hist Med 2011;24:334-51. https://doi.org/10.1093/shm/hkq051

(27) Almeida J. The differential incorporation of CAM into the medical establishment: The case of acupuncture and homeopathy in Portugal. Health Soc Rev 2012;21:5-22. https://doi.org/10.5172/hesr.2012.21.1.5

(28) Wahlberg A. A quackery with a difference New medical pluralism and the problem of 'dangerous practitioners' in the United Kingdom. Soc Sci Med 2007;65:2307-16. https://doi.org/10.1016/j.socscimed.2007.07.024

(29) Wiese M, Oster C. "Becoming accepted": The complementary and alternative medicine 
practitioners' response to the uptake and practice of traditional medicine therapies by mainstream health sector. Health 2010;14:41533.

https://doi.org/10.1177/1363459309359718

(30) Easthope G, Tranter B, Gill G. General practitioners' attitudes toward complementary therapies. Soc Sci Med 2000;51:1555-61. https://doi.org/10.1016/S0277-9536(00)000484

(31) Jong M, Lundqvist V, Miek C. A crosssectional study on Swedish licensed nurses' use, practice, perception and knowledge about complementary and alternative medicine. Scand J Caring Sci 2015;39:642-650. https://doi.org/10.1111/scs.12192

(32) Adams J, Tovey P (toim.) Complementary and alternative medicine in nursing and midwifery: Towards a critical social science. London, New York: Routledge; 2008.

(33) Mizrachi N, Shuval JT, Gross S. Boundary at work: Alternative medicine in biomedical settings. Soc Health Illn 2005;27:20-43. https://doi.org/10.1111/j.14679566.2005.00430.x

(34) Salomonsen L, Skovgaard L, la Cour S, ym. Use of complementary and alternative medicine at Norwegian and Danish hospitals. BMC Comp Altern Med 2011;11:4.

https://doi.org/10.1186/1472-6882-11-4

(35) Jacobsen R, Fonnebo VM, Foss N, ym. Use of complementary and alternative medicine within Norwegian hospitals. BMC Compl Altern Med 2015;15:275. https://doi.org/10.1186/s12906-015-0782-5

(36) Danell JA, Danell R. Publication activity in complementary and alternative medicine. Scientometrics 2009;80:539-551. https://doi.org/10.1007/s11192-008-2078-8

(37) Moral-Muñoz JA, Cobo MJ, Peis E, ym. Analyzing the research in integrative \& complementary medicine by means of science mapping. Complem Therap Med 2014;22:409_ 418.

https://doi.org/10.1016/j.ctim.2014.02.003

(38) Fu JJ, Zhang X, Zhao YH ym. Bibliometric analysis of complementary and alternative medicine research over three decades. Scientometrics 2011;88:617-626. https://doi.org/10.1007/s11192-011-0391-0

(39) World Health Organization. WHO Collaborating Centres for Traditional Medicine. Luettu 20.2.2018. http://www.who.int/ traditional-complementary-integrative-medicine/ collaboration/TM_CCs/en/

(40) Taloustutkimus. Kuluttajien näkemykset/ kokemukset eri sairauksien parantamiskeinoista. Suomen Apteekkariliitto, Lääketietokeskus Oy ja Suomen Lääkäriliitto; 2008.
(41) Vertanen P, Hänninen O, Piippo S, ym. Perinnehoitojen verhottu tieto. Kalevalainen kansanparannus -säätiö; 2017.

(42) Cochrane Complementary Medicine. Operational definition of complementary medicine. Luettu 20.2.2018. http://cam. cochrane.org/operational-definitioncomplementary-medicine

(43) Laiho K, Ouwehand A, Salminen S, Isolauri E. Inventing probiotic functional foods for patients with allergic disease. Ann Allergy, AsthmaImmunol 2002;89:75-82. https://doi.org/10.1016/S10811206(10)62128-X

(44) Lääketieteen sanastolautakunta. Uskomuslääkintä ei ole käännöstermi. Duod 2016;132:1390.

(45) Louhiala P. There is no alternative medicine. J Med Ethics: Medical Humanities 2010;36:115117. https://doi.org/10.1136/jmh.2010.004358

(46) Mäkelä M, Haapoja H. Puoskaroinnista lääketieteeseen ja takaisin. Duod 2016;132:2169-2175.

(47) Salmenniemi S. 'We can't live without beliefs': Self and society in therapeutic engagements. Sociol Rev 2017. doi: $10.1177 / 0038026116677194$ https://doi.org/10.1177/0038026116677194

(48) Brosnan C., Vuolanto P, Brodin Danell JA (toim.) Complementary and alternative medicine: Knowledge production and social transformation. Palgrave MacMillan. (ilmestyy huhtikuussa 2018)

Pia Vuolanto

YTT, TtM, sh

Tutkija

Tampereen yliopisto

Yhteiskuntatieteiden tiedekunta

Tiedon, tieteen, teknologian ja innovaatioiden tutkimuskeskus TaSTI

\section{Minna Sorsa}

TtT (hoitotiede), sh

Paulina Aarva

Dosentti, YTT

Tampereen yliopisto

Yhteiskuntatieteiden tiedekunta

Terveystieteet

KaIja Helin

TtT (hoitotiede) 


\section{ARTIKKELIT}

a1. Aarnio K, Lindeman M. Magical food and health beliefs: a portrait of believers and functions of the beliefs. Appetite 2004;43:65-74.

a2. Hämeen-Anttila KP, Niskala UR, Siponen SM, Ahonen RS. The use of complementary and alternative medicine products in preceding two days among Finnish parents - a population survey. BMC Complementary and Alternative Medicine. DOI: 10.1186/1472-6882-11-107.

a3. Hänninen $\mathrm{O}$, Räsänen V, Zaproudina N, ym. Tuki- ja Liikuntaelinkipujen perinnehoito vanhan kirjallisuuden ja tämän päivän havaintojen valossa. Hippokrates Suomen lääketieteen historian seuran vuosikirja 2004;21:13-26.

a4. Hernesniemi A. Jäsenkorjaajien käyttämät selkävaivojen hoitomenetelmät Pohjanmaalla. Duodecim 1989;105:758-763.

a5. Hernesniemi A. Kansanparantajan ja lääkärin yhteistyökokeilu. Suomen Lääkärilehti 1989;44: 800-802.

a6. Hinkka H, Kosunen E, Lammi U-K, Metsänoja R, Kellokumpu-Lehtinen P. Attitudes to terminal patients' unorthodox therapy: Finnish doctors' respondes to a case scenario. Support Care Cancer 2004;12:132-136.

a7. Hökkä M, Kaakinen P, Pölkki T. A systematic review: non-pharmacological interventions in treating pain in patients with advanced cancer. J Adv Nurs 2014;70:1954-69.

a8. Ilmanen A, Myllykangas M, Tuomainen T-P, ym. Lääkäreiden suhtautuminen vaihtoehtohoitoihin vuonna 2012. Suomen Lääkärilehti 2013;68:10141019.

a9. Klaukka T, Kujala A, Vertio H. Lääkäri ja vaihtoehtoiset hoitomuodot. Suomen Lääkärilehti 1988;43:2844-2847.

a10. Korvenranta E, Juntunen-Backman K, Mäntyranta, T. Luonnonlääkkeiden käyttö lasten allergioissa. Suomen Lääkärilehti 1996;51:300-303. a11. Lindeman M. Biases in intuitive reasoning and belief in complementary and alternative medicine. Psychology and Health 2011;26: 371-382.

a12. Niskala U, Ylinen S, Päkkilä H, ym. Täydentävät ja vaihtoehtoiset hoidot lasten itsehoidossa. Dosis 2009;25:186-195.

a13. Räisänen L, Räisänen S. Saamelaiset kansanparantajat. Duodecim 1981;97:703-708.

a14. Salmenperä L, Suominen T, Lauri S. Oncology nurses attituded towards alternative medicine. PsychoOncology 1998;7:453-459.

a15. Salmenperä L, Suominen T, Lauri S, ym. Attitudes of patients with breast and prostate cancer toward complementary therapies in Finland. Cancer Nursing 2001;24:328-334.

a16. Salmenperä L. The use of complementary therapies among breast and prostate cancer patients in Finland. European J Cancer Care 2002;11:44-50. a17. Salmenperä L, Suominen T, Vertio H. Physicians' attitudes towards the use of complementary therapies
(CTs) by cancer patients in Finland. European J Cancer Care 2003;12:358-364.

a18. Siponen SM, Ahonen RS, Kettis A, ym.

Complementary or alternative? Patterns of

complementary and alternative medicine (CAM) use among Finnish children. Eur J Clin Pharmacol 2012;68:1639-1645.

a19. Siponen S, Ahonen R, Kiviniemi V, ym. Association between parental attitudes and selfmedication of their children. Int J Clin Pharm 2013;35:113-120.

a20. Vaskilampi T, Hänninen O. Kuppaus kivun ja säryn hoitona nyky-Suomessa. Duodecim 1981;97:1174-1183.

a21. Meriläinen P, Vaskilampi T, Sinkkonen S. Kysely vaihtoehtoisten hoitomuotojen tutkimuksessa Esitutkimus vaihtoehtoisten hoitomuotojen käytöstä Kuopion ja Maaningan aikuisväestölle vuosina 1979 ja 1982. Kirjassa: Vaskilampi T (toim.) Vaihtoehtoisten hoitomuotojen tutkimuksen problematiikkaa. Jyväskylä: Yhteiskuntapolitiikan laitos, Jyväskylän yliopisto; 1986, 118-142.

a22. Vaskilampi T, Pylkkänen K. Luonnollinen ja yliluonnollinen vaihtoehtolääkinnässä. Duodecim 1991;107:1060-68.

a23. Vertio H, Klaukka T, Kujala S. Lääkärien suhtautuminen vaihtoehtohoitoihin, Suomen Lääkärilehti 1995;50:2227-2229.

a24. Wahlström M, Sihvo S, Haukkala A, ym. Use of mental health services and complementary and alternative medicine in persons with common mental disorders. Acta Psychiatr Scand 2008;118:73-80.

a25. Zaproudina N, Hänninen O, Airaksinen O.

Effectiveness of traditional bone setting in chronic neck pain: Randomized clinical trial. J Manipulat Physiol Therap 2007;30:432-437.

a26. Paal P. Patients' attitudes towards the use of complementary and alternative medicine in Finland: An ethnomedical insight based on cancer narratives. J Ethnol Folklor 2008;2:83-98.

a27. Vaskilampi T, Meriläinen P, Sinkkonen S. The use of alternative treatments in the Finnish adult population. Kirjassa: Lewith G. (toim.) Clinical Research Methodology for Complementary Therapies. London: Hodder \& Stoughton; 1993, 204-227.

a28. Hemmilä HM. Bone setting for prolonged neck pain: a randomized clinical trial. J Manipulative Physiol Ther 2005;28:508-15.

a29. Möttönen M, Uhari M. Use of micronutrients and alternative drugs by children with acute lymphoblastic leukemia. Medical and Pediatric Oncology 1997;28:205-208.

a30. Hemminki E, Mäntyranta T, Malin M, ym. A survey on the use of alternative drugs during pregnancy. Scand J Soc Med 1991;19:199-204. a31. Hedman J, Hugg T, Sandell J, Haahtela T. The effect of salt chamber treatment on bronchial hyperresponsiveness in asthmatics. Allergy: European Journal of Allergy and Clinical Immunology 2006;61(5):605-610. 
a32. Hernesniemi A. Jäsenkorjaajien hoitojen käyttö Pohjanmaalla, Sosiaalilääk Aikak 1988;25:288-296.

a33. Hernesniemi A. Meneillään olevaa tutkimusta: jäsenkorjaaja tutkimassa ja hoitamassa potilasta. Sosiaalilääk Aikak 1992;29:181-187.

a34. Vaskilampi T, Elo J, Myllykangas M. Kansanlääkinnän ja luontaistuotteiden käyttötutkimus kuopiolaisista vaatetusalan naistyöntekijöistä. Sosiaalilääk aikak 1984;21:149-157.

a35. Arkko P, Kari-Koskinen O, Kiviniitty

K. Kansanomaisia syövän hoitomenetelmiä I:

Koivuntuhkalipeän vaikutus rotan kloroomaan. Suomen Lääkärilehti 1980;35:1827-9.

a36. Meriläinen P. Kansanlääkinnän yleisyys Suomessa tällä hetkellä. Kirjassa: Hänninen $\mathrm{O}$, Sumuvuori H, Meriläinen P, Vaskilampi T. (toim.) Kansanparannus eilen ja tänään - huomisen tutkimushaaste.

Lääkintöhallituksen julkaisuja 96. Helsinki: Valtion painatuskeskus; 1987, 121-140.

a37. Vaskilampi T. Kansanlääkintä

yhteiskuntatieteellisen tutkimuksen kohteena. Kirjassa: Hänninen O, Sumuvuori H, Meriläinen P, Vaskilampi T. (toim.) Kansanparannus eilen ja tänään - huomisen tutkimushaaste. Lääkintöhallituksen julkaisuja 96. Helsinki: Valtion painatuskeskus; 1987, 141-155

a38. Salmenperä L, Suominen T. Vaihtoehtolääkintä - hoitamista vai humpuukia? Hoitajien tietoja ja mielipiteitä vaihtoehtolääkinnästä. Turku: Turun yliopisto, hoitotieteen laitoksen julkaisuja, sarja A13; 1996.

a39. Vartiainen E, Koskela K, Tikkanen J, ym. Vaihtoehtoisten hoitomuotojen käyttö Suomessa 1992. Kirjassa: Koskela K, Vaskilampi T, Vartiainen E, Meriläinen P, Viinamäki H, Mäntyranta T. (toim.) Vaihtoehtolääkintä Suomessa 1982-1992. Helsinki: Sosiaali- ja terveysministeriön selvityksiä 3; 1993, 13-36.

a40. Mäntyranta T, Vartiainen E, Hemminki E, ym. Luonnonlääkkeiden käyttö Suomessa. Kirjassa: Koskela K, Vaskilampi T, Vartiainen E, Meriläinen P, Viinamäki H, Mäntyranta T. (toim.) Vaihtoehtolääkintä Suomessa 1982-1992. Helsinki: Sosiaali- ja terveysministeriön selvityksiä 3; 1993, $37-52$

a41. Viinamäki H, Koskela K, Vartiainen E, ym. Kirjassa: Koskela K, Vaskilampi T, Vartiainen E, Meriläinen P, Viinamäki H, Mäntyranta T. (toim.) Vaihtoehtolääkintä Suomessa 1982-1992. Helsinki: Sosiaali- ja terveysministeriön selvityksiä 3; 1993 , 53-61.

a42. Vaskilampi T, Vartiainen E, Meriläinen P, ym. Vaihtoehtolääkinnän tuntemuksen ja käytön muutoksia - tuloksia kymmenvuotisseurannasta. Kirjassa: Koskela K, Vaskilampi T, Vartiainen E, Meriläinen P, Viinamäki H, Mäntyranta T. (toim.) Vaihtoehtolääkintä Suomessa 1982-1992. Helsinki: Sosiaali- ja terveysministeriön selvityksiä 3; 1993, 63-78.

a43. Meriläinen P, Vaskilampi T, Vartiainen E, ym. Suomalaisen väestön virallisten ja epävirallisten hoitomuotojen rinnakkaiskäyttö vuosina 1982 ja 1992. Kirjassa: Koskela K, Vaskilampi T, Vartiainen E, Meriläinen P, Viinamäki H, Mäntyranta T. (toim.) Vaihtoehtolääkintä Suomessa 1982-1992. Helsinki:
Sosiaali- ja terveysministeriön selvityksiä 3; 1993, 79-96.

a44. Toiviainen H. Lääkäreiden vaihdevuosihoitokäytännöt Helsinki: Stakes; 1997. a45. Hoffrén-Larsson R. Vanha intiaanikulttuureista periytyvä hoitomenetelmä, vyöhyketerapia, terveyden edistämisessä. Suomen Lääkärilehti 2000;55:26902692.

a46. Fock J, Pietilä K. Apteekkarien käsityksiä rohdosvalmisteista ja luontaistuotteista. Dosis 2007;23:106-115.

a47. Mikkonen M, Airaksinen M, Enlund H. Lääkkeitä, luonnonlääkkeitä vai kotikonsteja tutkimus kuopiolaisista luontaistuoteasiakkaista. Farmas Aikak Dosis 2000;16:30-39.

a48. Arkko P, Arkko B, Kari-Koskinen O, ym. The use of extract of birch ash as a cancer remedy in Northern Finland. Nordic Council Arct Med Res Rep 1982;32:5-8

a49. Mäntyranta T, Hemminki E, Kangas I, Topo P, Uutela A. Alternative drug use for the climacteric in Finland. Maturitas 1997;27(1):5-11.

a50. Nousiainen P, Merras-Salmio L, Aalto K, Kolho $\mathrm{K}$-. Complementary and alternative medicine use in adolescents with inflammatory bowel disease and juvenile idiopathic arthritis. BMC Complementary and Alternative Medicine 2014;14.

a51. Saarinen K, Jantunen J, Haahtela T. Birch pollen honey for birch pollen allergy - A randomized controlled pilot study. Int Arch Allergy Immunol 2011;155(2):160-166.

a52. Salminen E, Bishop M, Poussa T, Drummond R, Salminen S. Dietary attitudes and changes as well as use of supplements and complementary therapies by Australian and Finnish women following the diagnosis of breast cancer. Eur J Clin Nutr 2004;58(1):137-144. a53. Zheng A, Sakari R, Cheng SM, Hietikko A, Moilanen P, Timonen J, et al. Effects of a lowfrequency sound wave therapy programme on functional capacity, blood circulation and bone metabolism in frail old men and women. Clin Rehabil 2009;23(10):897-908.

\section{VÄITÖSKIRJAT}

A. Arkko P. Syövän kansanlääkinnän menetelmät Pohjois-Suomessa. Acta Universitatis Ouluensis, Series D, Medica 138, Medica Publica 5. Oulu: Oulun yliopisto; 1986.

B. Meriläinen P. Väestön terveydenhoidon kokonaisuus: Itsehoito, virallisten ja epävirallisten terveyspalvelujen käyttö sekä niitä määrittävät tekijät. Yhteiskuntatieteet, alkuperäistutkimukset 1. Kuopio: Kuopion yliopisto; 1986.

C. Raustia AM. Diagnosis and treatment of temporomandibular joint dysfunction. Advantages of computed tomography diagnosis. Stomatognathic treatment and acupuncture - a randomized trial. Department of Prosthodontics and Stomatognathic Physiology, Institute of Dentistry, University of Oulu and the Department of Diagnostic Radiology and Department of Physical Medicine and Rehabilitation, Oulu University Central Hospital. Oulu: Oulun yliopisto; 1986. 
D. Vaskilampi T. Vaihtoehtoinen terveydenhuolto hyvinvointivaltion terveysmarkkinoilla. Studies in Education, Psychology and Social Research 88. Jyväskylä: Jyväskylän yliopisto; 1992.

E. Frankberg-Lakkala H. Terveyttä ja hyvää oloa paastolla. Acta Universitatis Tamperensis A479. Tampere: Tampereen yliopisto; 1996.

F. Naakka-Korhonen M. Vaivasta taudiksi. Lapamatoon liittyvä kansanparannus erityisesti pohjoiskarjalaisen aineiston valossa. Helsinki: Suomalaisen kirjallisuuden seura; 1997.

G. Svennevig H. Hyvän olon hoidot. Kosketukseen perustuvien hoitojen käyttö hyvinvoinnin ja itseymmärryksen lisäämisen välineenä. Acta Universitatis Tamperensis 949. Tampere: Tampereen yliopisto; 2003.

H. Lindfors P. Homeopaatin vastaanotolla. Tutkimus vuorovaikutuksesta ja päätöksenteosta. Tampere:

Tampere University Press; 2005.
I. Salmenperä L. Complementary and alternative medicine; Attitudes of Cancer Patients, Nurses and Physicians, the Use of Complementary and Alternative Medicine by Cancer Patients. Series D, MedicaOdontologica 663. Turku: Turun yliopisto; 2005.

J. Strandberg H. Koppning i Finland fram till mitten av 1900-talet. Institutionen för filosofi, historia, kulturoch konstforskning. Helsinki: Helsingin yliopisto; 2012.

K. Vuolanto P. Boundary-work and the vulnerability of academic status : the case of Finnish nursing science. Tampere: Tampere University Press; 2013.

L. Siponen S. Children's health, self-care and the use of self-medication: population-based study in Finland. Publications of the University of Eastern Finland. Dissertations in Health Sciences 224. Kuopio: Terveystieteiden tiedekunta, farmasian laitos; 2014. 